\title{
Pengaruh Sertifikasi dan Kinerja Guru terhadap Prestasi Belajar Siswa
}

\author{
Rina Meiliyani ${ }^{1 凶}$, Happy Fitria ${ }^{2}$, Yenny Puspita ${ }^{3}$ \\ (1) Sekolah Menengah Atas Negeri Kecamatan Lais
}

(2) Universitas PGRI Palembang

$\triangle$ Corresponding author

[rinameiliyani3@gmail.com]

\begin{abstract}
Abstrak
Tujuan penelitian ini untuk mengetahui apakah terdapat pengaruh sertifikasi dan kinerja guru terhadap prestasi belajar siswa di SMA Kecamatan Lais Kabupaten Musi Banyuasin. Sampel penelitian terdiri dari 26 guru yang bersertifikat. Teknik pengumpulan data: 1) angket; 2) dokumentasi. Data dianalisis dengan menggunakan aplikasi software SPSS For Windows Version 21. Hasil penelitian ini adalah: 1) terdapat pengaruh yang signifikan sertifikasi terhadap prestasi belajar siswa di SMA Kecamatan Lais Kabupaten Musi Banyuasin; 2) terdapat pengaruh yang signifikan kinerja guru terhadap prestasi belajar siswa di SMA Kecamatan Lais Kabupaten Musi Banyuasin; 3) Ada pengaruh yang signifikan sertifikasi dan kinerja guru secara bersama-sama terhadap prestasi belajar siswa di SMA Kecamatan Lais Kabupaten Musi Banyuasin.
\end{abstract}

Kata Kunci: Sertifikasi; Kinerja Guru; Prestasi Siswa

\begin{abstract}
Research objectivesto determine whether there is an effect of certification and teacher performance on student's achievement in Senior High School Lais Sub-District in Musi Banyuasin regency. The research sample consisted of 26 teachers who were certified. Data collection techniques: 1) questionnaire; 2) documentation. The data were analyzed using the SPSS For Windows Version 21 software application. The results of the study were: 1 ) there was a significant effect of certification on student achievement in Senior High School Lais Sub-District in Musi Banyuasin regency; 2) there is a significant effect of teacher performance on student achievement in Senior High School Lais Sub-District in Musi Banyuasin regency; 3) there is a significant effect of certification and teacher performance together on student achievement of Senior High School Lais Sub-District in Musi Banyuasin regency.
\end{abstract}

Keyword: Certification; Teacher Performance; Student's Achievement

\section{PENDAHULUAN}

Tujuan pendidikan nasional tertuang dalam Undang-Undang Sisdiknas No. 20 Tahun 2003 pasal 3 berikut ini: "Pendidikan nasional berfungsi mengembangkan kemampuan dan membentuk watak serta peradaban bangsa yang bermartabat dalam rangka mencerdaskan kehidupan bangsa, bertujuan untuk berkembangnya potensi peserta didik agar menjadi manusia yang beriman dan bertakwa kepada Tuhan Yang Maha Esa, berakhlak mulia, sehat, berilmu, cakap, kreatif, mandiri, dan menjadi warga negara yang demokratis serta bertanggung jawab" Oleh sebab itu, transformasi sekolah era kontemporer menuju sekolah bermutu diawali dengan komitmen bersama terhadap mutu pendidikan oleh sekolah, administrator, guru, staf, siswa dan orang tua dalam komunitas sekolah. Dalam hal ini, mutu yang dimaksud yaitu kemampuan sumber daya sekolah mentransformasikan multi jenis masukan dan situasi untuk mencapai derajat nilai tambah tertentu dari peserta didik. Jika dilihat dari hasil pendidikan, mutu pendidikan dipandang berkualitas jika mampu melahirkan keunggulan akademis dan ekstrakurikuler pada peserta didik yang dinyatakan lulus untuk satu jenjang pendidikan atau menyelesaikan program pembelajaran tertentu.

Dunia pendidikan terus dituntut untuk dapat menghasilkan sumber daya manusia yang sesuai dengan kebutuhan masyarakat dan lapangan pekerjaan seiring dengan berkembangnya teknologi dan budaya masyarakat. Pemerintah telah berupaya meningkatkan kemampuan profesional guru diantaranya meningkatkan kualifikasi dan persyaratan jenjang pendidikan yang lebih tinggi bagi tenaga pengajar mulai tingkat usia dini sampai perguruan tinggi. Selain sertifikasi upaya lain yang telah ditentukan di Indonesia untuk meningkatkan kompetensi profesional guru misalnya, Pusat Kegiatan Guru (PKG), Kelompok Kerja Guru (KKG), maupun Musyawarah Guru Mata Pelajaran (MGMP) yang memungkinkan para guru untuk berbagi pengalaman dalam memecahkan masalah-masalah yang mereka hadapi dalam kegiatan mengajarnya. Mulyasa (2013:6) menyebutkan bahwa:"Pemerintah melakukan berbagai upaya untuk mengembangkan standar 
kompetensi dan sertifikasi guru, antara lain dengan disahkannya Undang-Undang Guru dan Dosen yang ditindaklanjuti dengan pengembangan Rancangan Peraturan Pemerintah (RPP) tentang guru dan dosen, yang dimaksudkan agar meningkatkan profesional dan kompetensi guru".

Dalam perkembangan pendidikan, peserta didik di masa yang akan datang diharapkan menjadi manusia Indonesia berkualitas yang senantiasa mampu memecahkan persoalan-persoalan kebutuhan hidupnya secara mandiri dan pada gilirannya dapat memberikan kontribusi dalam mewujudkan masyarakat adil dan sejahtera. Kadar kualitas SDM yang terukur akan menjadi tolok ukur untuk merekontruksi pendidikan dari waktu ke waktu. Salah satu barometer keberhasilan pendidikan dalam mewujudkan SDM adalah dengan mengukur kualitas SDM yang ditandai dengan meningkatnya kualitas pengetahuan, sikap, dan keterampilan yang lebih dinamis dan mandiri dalam kehidupan bermasyarakat, berbangsa dan beragama dengan tatanan nasional dan internasional (Aqib, 2009:14).

Guru dalam melaksanakan tugas mengajar senantiasa berkeinginan untuk meningkatkan kemampuan dalam memberikan pelayanan kepada siswa, masyarakat, dan lingkungan terutama lingkungan tempat bertugas. Dalam melaksanakan tugas ini guru berusaha untuk memenuhi kebutuhan dan keinginannya. Salah satunya dengan mengikuti sertifikasi sehingga memperoleh kesejahteraan dan kenyamanan yang lebih dalam melaksanakan tugas.

Secara formal, Undang-Undang Republik Indonesia Nomor 20 Tahun 2003 tentang Sistem Pendidikan Nasional, Undang-Undang Republik Indonesia Nomor 14 Tahun 2005 tentang Guru dan Dosen, dan Peraturan Pemerintah Nomor 19 Tahun 2005 tentang Standar Nasional Pendidikan menyatakan bahwa guru adalah tenaga profesional. Sebagai tenaga profesional, guru dipersyaratkan memiliki kualifikasi akademik S-1 (strata satu) atau D-4 (diploma empat) dalam bidang yang relevan dengan mata pelajaran yang diampunya dan menguasai kompetensi sebagai agen pembelajaran. Pemenuhan persyaratan kualifikasi akademik S-1/D-4 dibuktikan dengan ijazah yang diperolehnya dari lembaga pendidikan tinggi sedangkan persyaratan relevansinya dibuktikan dengan kesesuaian antara bidang pendidikan yang dimiliki dengan mata pelajaran yang diampu di sekolah. Sementara itu, persyaratan penguasaan kompetensi sebagai agen pembelajaran (yang meliputi kompetensi kepribadian, kompetensi pedagogik, kompetensi profesional, dan kompetensi sosial) dibuktikan dengan sertifikat sebagai pendidik.

Guru mempunyai kedudukan sebagai tenaga profesional pada jenjang pendidikan dasar, pendidikan menengah, dan pendidikan anak usia dini pada jalur pendidikan formal yang diangkat sesuai dengan peraturan perundang-undangan Lebih lanjut Undang-Undang Nomor 14 Tahun 2005 tentang Guru dan Dosen tersebut mendefinisikan bahwa profesional adalah pekerjaan atau kegiatan yang dilakukan oleh seseorang dan menjadi sumber penghasilan kehidupan yang memerlukan keahlian, kemahiran, atau kecakapan yang memenuhi standar mutu atau norma tertentu serta memerlukan pendidikan profesi.

Adapun tugas keprofesionalan guru dalam Undang-Undang Republik Indonesia Nomor 14 Tahun 2005 pasal 20 (a) Tentang Guru dan Dosen adalah merencanakan pembelajaran, melaksanakan proses pembelajaran yang bermutu, serta menilai dan mengevaluasi hasil pembelajaran. Tugas pokok guru yang diwujudkan dalam kegiatan belajar mengajar serta tugas-tugas guru dalam kelembagaan merupakan bentuk kinerja guru. Apabila kinerja guru meningkat, maka berpengaruh pada peningkatan kualitas keluaran atau outputnya.

Menurut Nanang (2013:39) ada empat ukuran seorang guru itu dinyatakan profesional: (1) memiliki komitmen pada siswa dan proses belajarnya, (2) secara mendalam menguasai bahan ajar dan cara mengajarkannya, (3) bertanggung jawab memantau kemampun belajar siswa melalui berbagai teknik evaluasi, (4) seyogianya menjadi bagian dari masyarakat belajar dalam lingkungan profesinya.

Dipertegas oleh Hasibuan (2014), seorang guru dapat dikatakan memiliki kemampuan jika memenuhi empat aspek, yaitu : 1) sifat, 2) kepribadian, 3) empati dan 4) menjalin kerjasama. Pada dasarnya terdapat seperangkat tugas yang harus dilaksanakan oleh guru terkait dengan profesinya sebagai pengajar, yakni (1) tugas dalam bidang profesi meliputi mendidik, mengajar dan melatih peserta didik; (2) tugas dalam bidang kemanusiaan meliputi bahwa guru di sekolah harus dapat menjadi orangtua kedua, dapat memahami peserta didik, membantu peserta didik dalam mentransformasikan dan mengidentifikasikan diri peserta itu sendiri; (3) tugas dalam bidang kemasyarakatan meliputi membantu masyarakat untuk dapat memperoleh ilmu pengetahuan dan mencerdaskan bangsa Indonesia seutuhnya berdasarkan Pancasila, (Uzer dalam Uno, 2008:20).

Lebih lanjut Syaodih (2010:68) mengemukakan bahwa dalam dunia pendidikan guru memikul tugas dan tanggung jawab yang tidak ringan, selain guru mendidik pintar anak muridnya secara akal, (mengasah kecerdesan IQ Intelligence Quotient), guru juga mendidik siswanya untuk santun dalam budi pekertinya. Menjadi guru yang profesional tidak cukup dengan penguasaan materi saja, akan tetapi mampu mengayomi murid, menjadi contoh atau teladan bagi murid, selalu mendorong murid untuk berbuat lebih baik dan maju, serta menjaga kode etik guru, seperti filosofi Ki Hajar Dewantoro "ing ngarso sung tuladha, ing madya mangun karso, tut wuri handayani". 
Menurut Sani (2017:6), dalam melaksanakan tugasnya, guru tidak berada dalam lingkungan yang kosong. la bagian dari dari sebuah "mesin besar" pendidikan nasional, dan karena itu ia terikat pada ramburambu yang telah ditetapkan secara nasional mengenai apa yang mesti dilakukannya. Hal seperti biasa dimanapun, namun dalam konteks profesionalisme guru dimana mengajar dianggap sebagai pekerjaan profesional, maka guru dituntut untuk profesional dalam melaksanakan tugasnya.

Tunjangan sertifikasi bukan hanya dimaksudkan untuk meningkatkan kesejahteraan guru, tetapi juga dimaksudkan untuk meningkatkan kompetensi dan komitmen kerja guru. Paradigma pertama, beranggapan bahwa kesejahteraan guru perlu ditingkatkan, agar mereka bisa menjalankan tugas mendidik generasi muda bangsa dengan baik. Menurut Undang-Undang Republik Indonesia Nomor 14 Tahun 2005 tentang Guru dan Dosen tertuang beberapa pasal tentang sertifikasi sebagai berikut : 1) Pasal 1 butir 11: sertifikasi adalah proses pemberian sertifikat pendidik kepada guru dan dosen; 2) Pasal 8: guru wajib memiliki kualifikasi akademik, kompetensi, sertifikat pendidik, sehat jasmani dan rohani, serta memiliki kemampuan untuk mewujudkan tujuan pendidikan nasional; 3) Pasal 11 butir 1: sertifikat pendidik sebagaimana dalam pasal 8 diberikan kepada guru yang telah memenuhi persyaratan; 4) Pasal 16: guru yang memiliki sertifikat pendidik memperoleh tunjangan profesi sebesar satu kali gaji, guru negeri maupun swasta dibayar pemerintah.

Dengan demikian sertifikasi adalah proses pemberian sertifikat kompetensi atau surat keterangan sebagai pengakuan terhadap kemampuan seseorang dalam melakukan suatu pekerjaan setelah lulus uji kompetensi. Peningkatan kompetensi guru pada dasarnya hanya merupakan satu aspek yang berperan dalam peningkatan kinerja dan motivasi guru sehingga dapat meningkatkan kualitas pendidikan.

Kinerja guru dipengaruhi oleh dua faktor, yaitu: faktor kemampuan dan faktor motivasi (Soekarno, 2009:2). Motivasi merupakan daya penggerak dari dalam dan di dalam subjek untuk melakukan aktivitasaktivitas tertentu demi mencapai suatu tujuan (Sardiman, 2013:73), bila motivasi kerjanya tinggi maka akan berpengaruh pada kinerja yang tinggi dan sebaliknya jika motivasinya rendah maka akan menyebabkan kinerja yang dimiliki tersebut rendah.

Peningkatan mutu guru lewat program sertifikasi sebagai upaya peningkatan mutu pendidikan. Rasionalnya adalah apabila kompetensi guru bagus diikuti dengan penghasilan bagus, diharapakan kinerjanya juga bagus. Apabila kinerja guru bagus maka KBM-nya juga bagus. KBM yang bagus diharapkan dapat membuahkan pendidikan yang bermutu. Pemikiran itulah yang mendasari bahwa guru perlu disertifikasi (Muslich, 2016:8).

Program sertifikasi merupakan program pemberian sertifikat bagi guru yang telah memenuhi sejumlah persyaratan menuju guru profesional. Guru yang telah memperoleh sertifikat profesi akan mendapatkan sejumlah hak yang antara lain berupa tunjangan profesi yang besarnya setara dengan satu kali gaji pokok guru tersebut. Program sertifikasi ini menjadi suatu keharusan bagi bangsa Indonesia di samping karena konsekuensi dari produk hukum di atas, juga secara hakiki karena tekad yang mendalam dari seluruh komponen bangsa yang ingin memperbaiki mutu pendidikan di negeri ini.

Pelaksanan uji sertifikasi tenaga pengajar/guru adalah untuk menilai kemampuan minimal yang harus dimiliki guru agar dapat melaksanakan tugas seorang guru dengan baik. Menurut Sarimaya (2018:12) program sertifikasi guru bertujuan untuk (1) menentukan kelayakan guru dalam melaksanakan tugas sebagai agen pembelajaran dan mewujudkan tujuan pendidikan nasional, (2) peningkatan proses dan mutu hasil pendidikan, dan (3) peningkatan profesionalisme guru.

Menurut Mangkunegara (2011:21) kinerja guru merupakan proses pembelajaran sebagai upaya mengembangkan kegiatan yang ada menjadi kegiatan yang lebih baik, sehingga tujuan pendidikan yang telah ditetapkan dicapai dengan baik melalui suatu kegiatan pembelajaran yang dilaksanakan oleh guru sesuai dengan target dan tujuan. Selanjutnya Rusyan (2016:47) mengemukakan bahwa kinerja guru adalah melaksanakan proses pembelajaran baik dilakukan di dalam kelas maupun di luar kelas di samping mengerjakan kegiatan-kegiatan lainnya, seperti mengerjakan administrasi sekolah dan administrasi pembelajaran, melaksanakan bimbingan dan layanan pada para siswa, serta melaksanakan penilaian.

\section{METODE PENELITIAN}

Metode dalam penelitian ini adalah metode kuantitatif dengan pendekatan survey. Sejalan dengan penelitian ini, menurut Sugiyono (2015:314) metode survey digunakan untuk mendapatkan data-data tempat terentu yang alamiah (bukan buatan), tetapi peneliti melakukan perlakuan dalam pengumpulan data misalnya dengan mengedarkan angket/kuesioner, test, wawancara terstruktur dan sebagainya (perlakuan tidak seperti dalam eksperimen). Sugiyono (2015:312) mengemukakan bahwa metode penelitian kuantitatif dapat diartikan sebagai metode penelitian yang berlandaskan pada filsafat positivisme, digunakan untuk meneliti pada populasi dan sampel tertentu, teknik pengambilan sampel pada umumnya dilakukan secara acak, pengumpulan data menggunakan instrumen penelitian, analisis data bersifat kuantitatif/statistik dengan tujuan untuk menguji hipotesis yang telah ditetapkan.

Berkaitan dengan penelitian tentang pengaruh sertifikasi dan kinerja guru terhadap prestasi belajar siswa SMA Negeri di Kecamatan Lais Kabupaten Musi Banyuasin, teknik pengumpulan data dalam penelitian 
ini menggunakan alat pengumpulan data yaitu, angket sebagai instrumen utama. Angket/kuesioner disajikan bervariasi dengan alternatif jawaban yakni: 1) Sangat Setuju (SS), 2) Setuju (S), 3) Ragu-Ragu (RG), 4) Tidak Setuju (TS), 5) Sangat Tidak Setuju (STS) (Sugiyono, 2015:199). Angket diberikan kepada guru- guru sampel di SMA Negeri Kecamatan Lais Kabupaten Musi Banyuasin sebanyak 26 orang guru.

Dokumentasi merupakan teknik pengumpulan data guna mendapatkan fakta-fakta tertulis yaitu berupa dokumen-dokumen, laporan- laporan, arsip-arsip dan atau bahan- bahan tertulis lain yang terkait dengan fokus penelitian (Arikunto, 2010:196). Berkaitan dengan teknik dokumentasi, peneliti mengambil data berupa foto-foto saat penelitian dilakukan dan notulen yang peneliti persiapkan sebagai data pendukung, maupun arsip surat-surat yang berkaitan dengan data penelitian

\section{HASIL DAN PEMBAHASAN}

Berdasarkan hasil yang diperoleh melalui uji coba angket sertifikasi sejumlah 20 butir pernyataan diperoleh hasil semuanya vallid dan memiliki nilai signifikan > dari 0,532 dengan taraf signifikansi $5 \%$, sehingga dapat diikutsertakan dalam penelitian selanjutnya. Berdasarkan hasil yang diperoleh melalui uji coba angket kinerja guru sejumlah 25 butir pernyataan diperoleh hasil semuanya vallid dan memiliki nilai signifikan > dari 0,532 dengan taraf signifikansi $5 \%$, sehingga dapat diikutsertakan dalam penelitian.

Berdasarkan hasil yang diperoleh melalui uji coba angket prestasi belajar sejumlah 25 butir pernyataan diperoleh hasil semuanya vallid dan memiliki nilai signifikan > dari 0,532 dengan taraf signifikansi $5 \%$, sehingga dapat diikutsertakan dalam penelitian selanjutnya.

Prayitno (2010:97) mengemukakan bahwa reliabilitas digunakan untuk mengetahui konsistensi alat ukur, apakah alat ukur yang digunakan dapat diandalkan dan tetap konsisten jika pengukuran tersebut diulang. Uji Reliabilitas yang digunakan dalam penelitian ini adalah metode Cronbach's Alpha. Pengambilan keputusan reliabilitas suatu variabel ditentukan dengan membandingkan nilai Cronbach's Alpha dengan nilai 0,6 . apabila Cronbach's Alpha >0,6, maka variabel yang diteliti adalah reliabel.

Berdasarkan hasil perhitungan reliabilitas instrumen angket sertifikasi, instrumen angket kinerja guru, instrumen angket prestasi belajar, diketahui bahwa hasil perhitungan reliabilitas instrumen angket disiplin diperoleh nilai sebesar 0,937 $>0,6$, hasil perhitungan instrumen angket motivasi kerja guru diperoleh nilai sebesar 0,935 >0,6, hasil perhitungan instrumen angket kinerja guru diperoleh nilai sebesar 0,938 $>0,6$. Dengan demikian, dapat dinyatakan bahwa semua variabel mempunyai koefisien Cronbach's Alpha > 0,6 sehingga dapat dikatakan bahwa semua konsep pengukuran masing-masing variabel dari angket yang di ujikan adalah reliabel yang berarti bahwa instrumen angket yang disebarkan dan digunakan dalam penelitian ini merupakan angket yang layak.

Berdasarkan hasil analisis data angket yang diperoleh dari jawaban guru yang memilih masing-masing pernyataan dengan variasi alternatif pilihan jawaban: 1 ) sangat setuju (SS) dengan nilai 5,2 ) setuju (S) dengan nilai 4, 3) ragu-ragu (RG) dengan nilai 3,4) tidak setuju (TS) dengan nilai 2,5 ) sangat tidak setuju (STS) dengan nilai 1 , pada masing-masing variabel angket yang diberikan kepada guru-guru sampel dalam penelitian ini dengan jumlah sebanyak 26 orang guru, diketahui bahwa pengaruh sertifikasi terhadap prestasi belajar siswa SMA Negeri di Kecamatan Lais Kabupaten Musi Banyuasin dinyatakan berdistribusi normal. Hal ini dibuktikan dengan nilai yang diperoleh dari analisis aplikasi software SPSS For Windows pada lajur Asymp. Sig. (2-tailed) diperoleh nilai sebesar 0,945 >0,05. Pengaruh kinerja guru terhadap prestasi belajar siswa SMA Negeri di Kecamatan Lais Kabupaten Musi Banyuasin dinyatakan berdistribusi normal. Hal ini dibuktikan dengan nilai yang diperoleh dari analisis aplikasi software SPSS For Windows pada lajur Asymp. Sig. (2-tailed) diperoleh nilai sebesar 0,382 >0,05. Pengaruh sertifikasi dan kinerja guru secara bersama-sama terhadap prestasi belajar siswa SMA Negeri di Kecamatan Lais Kabupaten Musi Banyuasin dinyatakan berdistribusi normal. Hal ini dibuktikan dengan nilai yang diperoleh dari analisis aplikasi software SPSS For Windows pada lajur Asymp. Sig. (2-tailed) diperoleh nilai sebesar 0,949>0,05.

Persentase pengaruh sertifikasi dan kinerja guru dalam penelitian ini mampu memberikan sumbangan pengaruh secara bersama-sama terhadap prestasi belajar siswa SMA Negeri di Kecamatan Lais Kabupaten Musi Banyuasin sebesar 46,6\%, sedangkan sisanya 53,4\% dipengaruhi oleh faktor- faktor lain yang tidak disebutkan di dalam penelitian ini.

Berdasarkan uraian uji normalitas data, diketahui bahwa pengaruh sertifikasi terhadap prestasi belajar siswa SMA Negeri di Kecamatan Lais Kabupaten Musi Banyuasin dinyatakan berdistribusi normal. Hal ini dibuktikan dengan nilai yang diperoleh dari analisis aplikasi software SPSS For Windows pada lajur Asymp. Sig. (2-tailed) diperoleh nilai sebesar 0,945 >0,05. Pengaruh kinerja guru terhadap prestasi belajar siswa SMA Negeri di Kecamatan Lais Kabupaten Musi Banyuasin dinyatakan berdistribusi normal. Hal ini dibuktikan dengan nilai yang diperoleh dari analisis aplikasi software SPSS For Windows pada lajur Asymp. Sig. (2-tailed) diperoleh nilai sebesar 0,382 >0,05. Pengaruh sertifikasi dan kinerja guru secara bersama-sama terhadap prestasi belajar siswa SMA Negeri di Kecamatan Lais Kabupaten Musi Banyuasin dinyatakan berdistribusi normal. Hal ini dibuktikan dengan nilai yang diperoleh dari analisis aplikasi software SPSS For Windows pada lajur Asymp. Sig. (2-tailed) diperoleh nilai sebesar 0,949 > 0,05. 
Berdasarkan uji homogenitas data menunjukkan bahwa hasil penyebaran instrumen angket pengaruh sertifikasi terhadap prestasi belajar siswa SMA Negeri di Kecamatan Lais Kabupaten Musi Banyuasin diperoleh melalui analisis aplikasi software SPSS For Windows Asymp. Sig. nilai sebesar $0.812>0,05$. Hasil penyebaran instrumen angket kinerja guru terhadap prestasi belajar siswa SMA Negeri di Kecamatan Lais Kabupaten Musi Banyuasin diperoleh nilai sebesar $0.758>0,05$. Hasil penyebaran instrumen angket pengaruh sertifikasi dan kinerja guru secara bersama-sama terhadap prestasi belajar siswa SMA Negeri di Kecamatan Lais Kabupaten Musi Banyuasin diperoleh nilai sebesar $0.958>0,05$. Dengan demikian, dapat dikatakan bahwa pengaruh sertifikasi dan kinerja guru baik secara parsial maupun secara simultan memberikan pengaruh terhadap prestasi belajar siswa SMA Negeri di Kecamatan Lais Kabupaten Musi Banyuasin dan dapat dikatakan berhomogen.

Berdasarkan uji linearitas sertifikasi terhadap prestasi belajar siswa SMA Negeri di Kecamatan Lais Kabupaten Musi Banyuasin di atas, secara parsial menunjukkan bahwa Fhitung > Ftabel yaitu nilai pada lajur deviation from linearity sebesar 1,142 > 0,05. Dengan demikian dapat dikatakan bahwa ada pengaruh yang signifikan sertifikasi terhadap prestasi belajar siswa SMA Negeri di Kecamatan Lais Kabupaten Musi Banyuasin, dan dapat dikatakan memiliki linear.

Berdasarkan uji linearitas kinerja guru terhadap prestasi belajar siswa SMA Negeri di Kecamatan Lais Kabupaten Musi Banyuasin di atas, secara parsial menunjukkan bahwa Fhitung > Ftabel yaitu nilai pada lajur deviation from linearity sebesar 1,144 >0,05. Dengan demikian dapat dikatakan bahwa ada pengaruh yang signifikan kinerja guru terhadap prestasi belajar siswa SMA Negeri di Kecamatan Lais Kabupaten Musi Banyuasin, dan dapat dikatakan memiliki linear.

Berdasarkan uji linearitas pengaruh sertifikasi dan kinerja guru secara bersama-sama terhadap prestasi belajar siswa SMA Negeri di Kecamatan Lais Kabupaten Musi Banyuasin diperoleh nilai Fhitung > Ftabel yaitu nilai pada lajur deviation from linearity sebesar 1,181 >0,05. Dengan demikian dapat dikatakan bahwa ada pengaruh yang signifikan pengaruh sertifikasi dan kinerja guru secara bersama-sama terhadap prestasi belajar siswa SMA Negeri di Kecamatan Lais Kabupaten Musi Banyuasin, dan dapat dikatakan memiliki linear.

Berdasarkan uji hipotesis dilakukan tiga tahap guna untuk mencari kebenaran hipotesis penelitian yang diasumsikan. Hipotesis statistik didefinisikan sebagai pernyataan matematis tentang parametriks yang akan diuji sejauhmana suatu data sampel mendukung kebenaran hipotesis tersebut. Hipotesis merupakan kesimpulan sementara yang masih harus di uji kebenarannya. Melalui analisis statistik inferensial yang merupakan analisis regresi linear sederhana dan analisis regresi linear berganda untuk menjelaskan hasil yang diperoleh melalui analisis dengan menggunakan program aplikasi software SPSS versi 21 yang digunakan dalam menguji hipotesis yang ada. Analisis regresi linear baik secara parsial ataupun simultan ini terdiri dari analisis koefisien determinasi, koefisien regresi linear parsial (uji-t), dan koefisien regresi simultan (uji-f). Koefisien regresi linear sering dikenal sebagai pengujian hipotesis secara parsial atau menguji pengaruh tiap variabel independen ke variabel dependent atau pengaruh sertifikasi terhadap prestasi belajar siswa SMA Negeri di Kecamatan Lais Kabupaten Musi Banyuasin, pengaruh kinerja guru terhadap prestasi belajar siswa SMA Negeri di Kecamatan Lais Kabupaten Musi Banyuasin, maupun menguji pengaruh sertifikasi dan kinerja guru secara bersama-sama terhadap prestasi belajar siswa SMA Negeri di Kecamatan Lais Kabupaten Musi Banyuasin.

Berdasarkan hasil analisis koefisien determinasi dengan menggunakan regresi linear sederhana pengaruh sertifikasi terhadap prestasi belajar siswa SMA Negeri di Kecamatan Lais Kabupaten Musi Banyuasin, berdasarkan nilai output Model Summary diperoleh angka R sebesar 0,510. Dengan demikian, dapat dikatakan bahwa sertifikasi memberikan pengaruh yang cukup kuat terhadap terhadap kinerja guru SMP Negeri di Kecamatan Wonosari Prabumulih Utara dengan dibuktikan nilai korelasi berada di antara 0,400 - 0,599. Standar Error of Estimated (Standar Deviasi) artinya mengukur variasi dari nilai yang diprediksi. Dalam penelitian ini standar deviasinya sebesar 1,5990. semakin kecil standar deviasi berarti model semakin baik.

Analisis koesifien determinasi digunakan untuk mengetahui presentase sumbangan pengaruh variabel independen terhadap variabel dependent. Berdasarkan dapat dijelaskan bahwa angka yang diperoleh koefisien determinasi R Square (R2) sebesar 0,260 yang berarti bahwa persentase pengaruh sertifikasi mampu menyumbang pengaruh terhadap prestasi belajar siswa SMA Negeri di Kecamatan Lais Kabupaten Musi Banyuasin sebesar 26\%.

Berdasarkan angka koefisien konstanta (Constant) $=4,943$ dan angka koefisien lingkungan kerja diperoleh angka sebesar 0,319 , sehingga diperoleh persamaan regresi linear sederhana $\hat{Y}=4,943+0,319$, atau persamaan regresi secara parsial antara variabel X1 terhadap $Y$ adalah $=4,943+0,319$ X1. Selanjutnya persamaan tersebut digunakan untuk menjelaskan pengaruh sertifikasi terhadap prestasi belajar siswa SMA Negeri di Kecamatan Lais Kabupaten Musi Banyuasin.

Hasil analisis koefisien diperoleh thitung sebesar 11,857. kriteria uji hipotesis jika thitung $>$ ttabel maka Ha diterima sedangkan jika thitung < ttabel maka Ha ditolak dan untuk menentukan ttabel dicari pada a 
$=5 \%: 2=2,5 \%$ (uji 2 sisi) dengan derajat kebebasan $(\mathrm{df})=n-k$ atau $\mathrm{df}=26-2=24$ ( $\mathrm{n}$ adalah jumlah sampel dan $\mathrm{k}$ adalah jumlah variabel independet). Dengan pengujian dua sisi (signifikan $=0,025$ ) hasil diperoleh untuk ttabel sebesar 3,708. berdasarkan penjelasan di atas yaitu thitung $=11,857$ dan ttabel $=4,943$, maka thitung > ttabel yang berarti Ho ditolak dan Ha diterima. Dengan demikian dapat dikatakan bahwa secara parsial dinyatakan ada pengaruh yang signifikan sertifikasi terhadap prestasi belajar siswa SMA Negeri di Kecamatan Lais Kabupaten Musi Banyuasin.

Berdasarkan hasil analisis koefisien determinasi dengan menggunakan regresi linear sederhana motivasi kerja guru terhadap terhadap kinerja guru SMP Negeri di Kecamatan Wonosari Prabumulih Utara berdasarkan nilai output Model Summary diperoleh angka $\mathrm{R}$ sebesar 0,440 . Dengan demikian, dapat dikatakan bahwa motivasi kerja guru mampu memberikan pengaruh cukup kuat terhadap kinerja guru SMP Negeri di Kecamatan Wonosari Prabumulih Utara dengan dibuktikan nilai korelasi berada di antara 0,400 0,599. Standar Error of Estimated (Standar Deviasi) artinya mengukur variasi dari nilai yang diprediksi. Dalam penelitian ini standar deviasinya sebesar 1,7737. semakin kecil standar deviasi berarti model semakin baik.

Berdasarkan angka koefisien konstanta (Constant) $=4,943$ dan angka koefisien lingkungan kerja diperoleh angka sebesar 0,319, sehingga diperoleh persamaan regresi linear sederhana $\hat{Y}=4,943+0,319$, atau persamaan regresi secara parsial antara variabel X1 terhadap $Y$ adalah $=4,943+0,319 X 1$. Selanjutnya persamaan tersebut digunakan untuk menjelaskan pengaruh sertifikasi terhadap prestasi belajar siswa SMA Negeri di Kecamatan Lais Kabupaten Musi Banyuasin.

Hasil analisis koefisien diperoleh thitung sebesar 11,857. kriteria uji hipotesis jika thitung > ttabel maka Ha diterima sedangkan jika thitung < ttabel maka Ha ditolak dan untuk menentukan ttabel dicari pada a $=5 \%: 2=2,5 \%$ (uji 2 sisi) dengan derajat kebebasan $(\mathrm{df})=n-k$ atau $\mathrm{df}=26-2=24$ ( $\mathrm{n}$ adalah jumlah sampel dan $k$ adalah jumlah variabel independet). Dengan pengujian dua sisi (signifikan $=0,025$ ) hasil diperoleh untuk ttabel sebesar 3,708. berdasarkan penjelasan di atas yaitu thitung $=11,857$ dan ttabel $=4,943$, maka thitung > ttabel yang berarti Ho ditolak dan Ha diterima. Dengan demikian dapat dikatakan bahwa secara parsial dinyatakan ada pengaruh yang signifikan sertifikasi terhadap prestasi belajar siswa SMA Negeri di Kecamatan Lais Kabupaten Musi Banyuasin.

Berdasarkan hasil analisis koefisien determinasi dengan menggunakan regresi linear sederhana kinerja guru terhadap prestasi belajar siswa SMA Negeri di Kecamatan Lais Kabupaten Musi Banyuasin berdasarkan nilai output Model Summary diperoleh angka $\mathrm{R}$ sebesar 0,460. Dengan demikian, dapat dikatakan bahwa kinerja guru mampu memberikan pengaruh cukup kuat terhadap prestasi belajar siswa SMA Negeri di Kecamatan Lais Kabupaten Musi Banyuasin dengan dibuktikan nilai korelasi berada di antara 0,400 - 0,599. Standar Error of Estimated (Standar Deviasi) artinya mengukur variasi dari nilai yang diprediksi. Dalam penelitian ini standar deviasinya sebesar 1,6498. semakin kecil standar deviasi berarti model semakin baik.

Analisis koesifien determinasi digunakan untuk mengetahui presentase sumbangan pengaruh motivasi kerja guru terhadap kinerja guru SMP Negeri di Kecamatan Wonosari Prabumulih Utara bahwa angka yang diperoleh koefisien determinasi R Square (R2) sebesar 0,212 yang berarti bahwa persentase pengaruh kinerja guru mampu memberikan sumbangan pengaruh terhadap prestasi belajar siswa SMA Negeri di Kecamatan Lais Kabupaten Musi Banyuasin, sebesar 21,2\%.

Berdasarkan hasil koefisien analisis regresi linear sederhana secara parsial pengaruh kinerja guru terhadap prestasi belajar siswa SMA Negeri di Kecamatan Lais Kabupaten Musi Banyuasin diperoleh angka koefisien konstanta (Constant) $=2,776$ dan angka koefisien $X 2=0,252$, sehingga diperoleh persamaan regresi linear sederhana $\hat{Y}=2,776+0,252 X 2$ atau persamaan regresi linear sederhana secara parsial antara variabel X2. Selanjutnya persamaan tersebut digunakan untuk menjelaskan pengaruh kinerja guru terhadap prestasi belajar siswa SMA Negeri di Kecamatan Lais Kabupaten Musi Banyuasin.

Hasil analisis koefisien diperoleh thitung sebesar 7,314 kriteria uji hipotesis jika thitung > ttabel maka Ha diterima sedangkan jika thitung < ttabel maka Ha ditolak dan untuk menentukan ttabel dicari pada $\mathrm{a}=5 \%$ $: 2=2,5 \%$ (uji 2 sisi) dengan derajat kebebasan $(\mathrm{df})=\mathrm{n}-\mathrm{k}$ atau $\mathrm{df}=26-2=24$ ( $\mathrm{n}$ adalah jumlah sampel dan $\mathrm{k}$ adalah jumlah variabel independet). Dengan pengujian dua sisi (signifikan $=0,025$ ) hasil diperoleh untuk ttabel sebesar 2,776. Berdasarkan penjelasan di atas yaitu thitung $=7,314$ dan ttabel $=2,776$, maka thitung $>$ ttabel yang berarti Ho ditolak dan Ha diterima. Dengan demikian dapat dikatakan bahwa secara parsial ada pengaruh yang signifikan kinerja guru terhadap prestasi belajar siswa SMA Negeri di Kecamatan Lais Kabupaten Musi Banyuasin.

Berdasarkan tujuan penelitian yang diajukan untuk mengetahui ada tidaknya pengaruh sertifikasi dan kinerja guru secara bersama-sama terhadap prestasi belajar siswa SMA Negeri di Kecamatan Lais Kabupaten Musi Banyuasin dan asumsi yang diajukan pada hipotesis penelitian ini adalah ada pengaruh yang signifikan sertifikasi dan kinerja guru secara bersama-sama terhadap prestasi belajar siswa SMA Negeri di Kecamatan Lais Kabupaten Musi Banyuasin.

Berdasarkan hasil analisis koefisien regresi linear berganda ada pengaruh yang signifikan sertifikasi dan kinerja guru secara bersama-sama terhadap prestasi belajar siswa SMA Negeri di Kecamatan Lais 
Kabupaten Musi Banyuasin diperoleh angka koefisien konstanta (Constant) $=3,981$, koefisien regresi sederhana pengaruh sertifikasi terhadap prestasi belajar siswa SMA Negeri di Kecamatan Lais Kabupaten Musi Banyuasin diperoleh nilai sebesar 3,311, koefisien regresi sederhana pengaruh kinerja guru terhadap prestasi belajar siswa SMA Negeri di Kecamatan Lais Kabupaten Musi Banyuasin diperoleh nilai sebesar 2,984, dan koefisien regresi berganda sertifikasi dan kinerja guru secara bersama-sama terhadap prestasi belajar siswa SMA Negeri di Kecamatan Lais Kabupaten Musi Banyuasin diperoleh nilai sebesar 8,225.

Berdasarkan nilai yang diperoleh, koefisien regresi linear berganda $Y=3,981+3,311 X 1+2,984 X 2$. Selanjutnya persamaan tersebut digunakan untuk menjelaskan pengaruh sertifikasi dan kinerja guru secara bersama-sama terhadap prestasi belajar siswa SMA Negeri di Kecamatan Lais Kabupaten Musi Banyuasin.

Berdasarkan nilai koefisien regresi berganda diperoleh nilai THitung > TTabel, pengaruh sertifikasi dan kinerja guru secara bersama-sama terhadap prestasi belajar siswa SMA Negeri di Kecamatan Lais Kabupaten Musi Banyuasin dengan nilai sebesar 8,225 > 3,981. Dengan demikian, analisis hipotesis ketiga, dinyatakan ada pengaruh yang signifikan sertifikasi dan kinerja guru secara bersama-sama terhadap prestasi belajar siswa SMA Negeri di Kecamatan Lais Kabupaten Musi Banyuasin. (Analisis penelitian dengan menggunakan aplikasi software SPSS For Windows).

Berdasarkan hasil analisis pengaruh sertifikasi dan kinerja guru secara bersama-sama terhadap prestasi belajar siswa SMA Negeri di Kecamatan Lais Kabupaten Musi Banyuasin, hasil analisis regresi linear berganda berdasarkan output Model Summary diperoleh angka R sebesar 0,683. Dengan demikian, dapat dikatakan bahwa persentase pengaruh sertifiasi dan kinerja guru mampu memberikan sumbangan pengaruh kuat terhadap prestasi belajar siswa SMA Negeri di Kecamatan Lais Kabupaten Musi Banyuasin. Karena nilai korelasi ganda berada di antara 0,500 - 0,699. Standar Error of Estimated (Standar Deviasi) artinya mengukur variasi dari nilai yang diprediksi. Dalam penelitian ini standar deviasinya sebesar 1,3869, semakin kecil standar deviasi berarti model semakin baik.

Analisis koesifien determinasi digunakan untuk mengetahui presentase sumbangan pengaruh sertifikasi dan kinerja guru secara bersama-sama terhadap prestasi belajar siswa SMA Negeri di Kecamatan Lais Kabupaten Musi Banyuasin diperoleh koefisien determinasi R Square (R2) sebesar 0,466 yang berarti bahwa sumbangan persentase pengaruh sertifikasi dan kinerja guru mampu menyumbang pengaruh terhadap prestasi dipengaruhi oleh faktor-faktor lain yang tidak disebutkan di dalam penelitian ini.

Berdasarkan hasil analisis regresi linear berganda dinyatakan bahwa ada pengaruh yang signifikan sertifikasi dan kinerja guru secara bersama-sama terhadap prestasi belajar siswa SMA Negeri di Kecamatan Lais Kabupaten Musi Banyuasin, berdasarkan nilai Fhitung diketahui bahwa nilai yang diperoleh 10,046. Kriteria uji hipotesis jika Fhitung > Ftabel maka Ha diterima, dan jika sebaliknya Fhitung < Ftabel maka Ha ditolak. Berdasarkan Ftabel pada taraf nyata $(0,05)$ dengan db pembilang 2 (ditentukan dari banyaknya variabel bebas dan db penyebut 26 (ditentukan dari banyak sampel dikurang variabel bebas dikurang satu) atau dapat ditentukan melalui aplikasi program Excell pada sel kosong ketik rumus $=\operatorname{FINV}(0,05,10,046)$ diperoleh angka sebesar 0,386 (Prayitno, 2010:116).

Berdasarkan penjelasan di atas diketahui Fhitung $=10,046$ dan Ftabel 0,386 dimana Fhitung $>$ Ftabel atau 10,046 > 0,386 yang berarti Ha diterima atau dapat dikatakan bahwa ada pengaruh yang signifikan sertifikasi dan kinerja guru secara bersama-sama terhadap prestasi belajar siswa SMA Negeri di Kecamatan Lais Kabupaten Musi Banyuasin.

Berdasarkan kajian teoretik turut mendukung di dalam kajian penelitian ini, seperti yang dikemukakan oleh Aqib (2009:14) bahwa dalam perkembangan pendidikan, peserta didik di masa yang akan datang diharapkan menjadi manusia Indonesia berkualitas yang senantiasa mampu memecahkan persoalanpersoalan kebutuhan hidupnya secara mandiri dan pada gilirannya dapat memberikan kontribusi dalam mewujudkan masyarakat adil dan sejahtera. Kadar kualitas SDM yang terukur akan menjadi tolok ukur untuk merekontruksi pendidikan dari waktu ke waktu. Salah satu barometer pengetahuan, sikap, dan keterampilan yang lebih dinamis dan mandiri dalam kehidupan bermasyarakat, berbangsa dan beragama dengan tatanan nasional dan internasional.

Guru mempunyai kedudukan sebagai tenaga profesional pada jenjang pendidikan dasar, pendidikan menengah, dan pendidikan anak usia dini pada jalur pendidikan formal yang diangkat sesuai dengan peraturan perundang-undangan Lebih lanjut Undang-Undang Nomor 14 Tahun 2005 tentang Guru dan Dosen tersebut mendefinisikan bahwa profesional adalah pekerjaan atau kegiatan yang dilakukan oleh seseorang dan menjadi sumber penghasilan kehidupan yang memerlukan keahlian, kemahiran, atau kecakapan yang memenuhi standar mutu atau norma tertentu serta memerlukan pendidikan profesi.

Adapun tugas keprofesionalan guru dalam Undang-Undang Republik Indonesia Nomor 14 Tahun 2005 pasal 20 (a) Tentang Guru dan Dosen adalah merencanakan pembelajaran, melaksanakan proses pembelajaran yang bermutu, serta menilai dan mengevaluasi hasil pembelajaran. Tugas pokok guru yang diwujudkan dalam kegiatan belajar mengajar serta tugas-tugas guru dalam kelembagaan merupakan bentuk kinerja guru. Apabila kinerja guru meningkat, maka berpengaruh pada peningkatan kualitas keluaran atau outputnya. 
Menurut Nanang (2013:39) ada empat ukuran seorang guru itu dinyatakan profesional: (1) memiliki komitmen pada siswa dan proses belajarnya, (2) secara mendalam menguasai bahan ajar dan cara mengajarkannya, (3) bertanggung jawab memantau kemampun belajar siswa melalui berbagai teknik evaluasi, (4) seyogianya menjadi bagian dari masyarakat belajar dalam lingkungan profesinya.

Dipertegas oleh Hasibuan (2014), seorang guru dapat dikatakan memiliki kemampuan jika memenuhi empat aspek, yaitu : 1) sifat, 2) kepribadian, 3) empati dan 4) menjalin kerjasama. Pada dasarnya terdapat seperangkat tugas yang harus dilaksanakan oleh guru terkait dengan profesinya sebagai pengajar, yakni (1) tugas dalam bidang profesi meliputi mendidik, mengajar dan melatih peserta didik; (2) tugas dalam bidang kemanusiaan meliputi bahwa guru di sekolah harus dapat menjadi orangtua kedua, dapat memahami peserta didik, membantu peserta didik dalam mentransformasikan dan mengidentifikasikan diri peserta itu sendiri; (3) tugas dalam bidang kemasyarakatan meliputi membantu masyarakat untuk dapat memperoleh ilmu pengetahuan dan mencerdaskan bangsa Indonesia seutuhnya berdasarkan Pancasila, (Uzer dalam Uno, 2008:20).

Tunjangan sertifikasi bukan hanya dimaksudkan untuk meningkatkan kesejahteraan guru, tetapi juga dimaksudkan untuk meningkatkan kompetensi dan komitmen kerja guru. Paradigma pertama, beranggapan bahwa kesejahteraan guru perlu ditingkatkan, agar mereka bisa menjalankan tugas mendidik generasi muda bangsa dengan baik. Menurut Undang-Undang Republik Indonesia Nomor 14 Tahun 2005 tentang Guru dan Dosen tertuang beberapa pasal tentang sertifikasi sebagai berikut : 1) Pasal 1 butir 11: sertifikasi adalah proses pemberian sertifikat pendidik kepada guru dan dosen; 2) Pasal 8: guru wajib memiliki kualifikasi akademik, kompetensi, sertifikat pendidik, sehat jasmani dan rohani, serta memiliki kemampuan untuk mewujudkan tujuan pendidikan nasional; 3) Pasal 11 butir 1: sertifikat pendidik sebagaimana dalam pasal 8 diberikan kepada guru yang telah memenuhi persyaratan; 4) Pasal 16: guru yang memiliki sertifikat pendidik memperoleh tunjangan profesi sebesar satu kali gaji, guru negeri maupun swasta dibayar pemerintah.

Dengan demikian sertifikasi adalah proses pemberian sertifikat kompetensi atau surat keterangan sebagai pengakuan terhadap kemampuan seseorang dalam melakukan suatu pekerjaan setelah lulus uji kompetensi. Peningkatan kompetensi guru pada dasarnya hanya merupakan satu aspek yang berperan dalam peningkatan kinerja dan motivasi guru sehingga dapat meningkatkan kualitas pendidikan.

Kinerja guru dipengaruhi oleh dua faktor, yaitu: faktor kemampuan dan faktor motivasi (Soekarno, 2009:2). Motivasi merupakan daya penggerak dari dalam dan di dalam subjek untuk melakukan aktivitasaktivitas tertentu demi mencapai suatu tujuan (Sardiman, 2013:73), bila motivasi kerjanya tinggi maka akan berpengaruh pada kinerja yang tinggi dan sebaliknya jika motivasinya rendah maka akan menyebabkan kinerja yang dimiliki tersebut rendah

\section{SIMPULAN}

Ada pengaruh sertifikasi terhadap prestasi belajar siswa SMA Negeri di Kecamatan Lais Kabupaten Musi Banyuasin. Ada pengaruh kinerja guru terhadap prestasi belajar siswa SMA Negeri di Kecamatan Lais Kabupaten Musi Banyuasin. Ada pengaruh sertifikasi dan kinerja guru secara bersama-sama terhadap prestasi belajar siswa SMA Negeri di Kecamatan Lais Kabupaten Musi Banyuasin.

\section{UCAPAN TERIMA KASIH}

Terima kasih yang sebesar-besarnya kami ucapkan kepada teman-teman dan semua pihak yang banyak membantu kami dalam menyelesaikan artikel ini sehingga dapat dipublikasikan.

\section{DAFTAR PUSTAKA}

Arikunto, S. (2010). Prosedur Penelitian Suatu Pendekatan Praktek. Edisi Revisi. Jakarta: Rineka Cipta.

Aqib, Z. (2009). Menjadi Guru Profesional Berstandar Nasional. Bandung: Yrama Widya. Departemen Pendidikan Nasional

Undang-Undang Nomor 14 Tahun 2004. Guru dan Dosen. Jakarta: Departemen Pendidikan Nasional Republik Indonesia.

Hasibuan, M. S. P. (2014). Manajemen Sumber Daya Manusia. Jakarta: Bumi Aksara.

Mangkunegara. (2011). Jurnal: Kinerja Guru dan Upaya Meningkatkannya. Jakarta: www.emaskuwinggomangkunegara.html. (Diakses pada 20 November 2019).

Muslich, M. (2016). Sertifikasi Guru Menuju Profesionalisme Pendidik. Jakarata: Bumi Aksara

Mulyasa. (2013). Menjadi Guru Profesional. Bandung: Remaja Rosdakarya.

Nanang. (2013.) Strategi Pendidikan. Jakarta: Raja Graffindo Persada.

Peraturan Pemerintah Nomor 19 Tahun 2005 tentang Standar Nasional Pendidikan. Jakarta: Departemen Pendidikan Nasional Republik Indonesia. 
Rusyan. (2016). Manajemen Peningkatan Kinerja Guru. Konsep Strategi dan Implementasi. Bandung: Remaja Rosdakarya.

Sani, B. (2017). Kompetensi Pedagogik, Teori dan Praktik Untuk Peningkatan Kinerja dan Kualitas Guru. Jakarta: Kata Pena.

Sardiman. (2013). Interaksi dan Motivasi Belajar Mengajar. Jakarta: Raja Grafindo Persada

Sarimaya, F. (2018). Sertifikasi Guru Apa, Mengapa dan Bagaimana?. Bandung: Yrama Widya.

Sugiyono. (2015). Metode Penelitian Pendidikan, Pendekatan Kuantitatif, Kualitatif dan R \& D. Bandung: Alfabeta.

Syaodih N. (2010). Landasan Psikologi Proses Pendidikan. Bandung: Remaja Rosdakarya.

Soekarno, P. R. (2009). Kinerja Guru dan Faktor-Faktor yang Mempengaruhinya. http://cindoprameswari.com/2009/02/kinerja-guru-dan-faktor-faktor-yangmempengaruhinya.html (20 November 2019).

UU No. 14 tahun 2004 tentang Guru dan Dosen. Direktorat Jenderal Pendidikan Dasar dan Menengah, Depdiknas RI.

Undang-Undang Nomor 20 Tahun 2003 Tentang Sistem Pendidikan Nasional. Jakarta: Direktorat Jenderal Pendidikan Dasar dan Menengah, Depdiknas RI

Undang-Undang Republik Indonesia Nomor 14 Tahun 2005 tentang Guru dan Dosen. Jakarta: Departemen Pendidikan Nasional Republik Indonesia.

Uno, H. B. (2008). Profesi Kependidikan. Jakarta: Bumi Aksara 